\title{
Factors Affecting Purchase Decisions: Horison Hotels West Java Area
}

\author{
Arif Zulkarnain \\ Hotel Management Department, Faculty of Economics and \\ Communication \\ Bina Nusantara University \\ Jakarta, Indonesia \\ arief.zulkarnain@binus.edu
}

\author{
Maryani \\ Information Systems Department, School of Information Systems \\ Bina Nusantara University \\ Jakarta, Indonesia \\ yanie@binus.edu
}

\author{
Trias Septyoari Putranto \\ Hotel Management Department, Faculty of Economics and \\ Communication \\ Bina Nusantara University \\ Jakarta, Indonesia \\ asep.syaiful@podomorouniversity.ac.id
}

\author{
Leonandri Dino \\ Hotel Management Program \\ Sekolah Tinggi Pariwisata Trisakti \\ Jakarta, Indonesia \\ dinoleonandri@stptrisakti.ac.id
}

\begin{abstract}
The purpose of this study aims to develop and test a conceptual model of the relationships between the constructs of Brand Image, Price, Service Quality and Purchase Decisions in the hospitality industry. The discussion in this study focuses on (1) the effect of brand image on purchase decisions; (2) the effect of hotel price on purchase decisions; (3) the effect of service quality on purchase decisions; and (4) simultaneous effect on brand image, room price and service quality on purchase decisions. Primary data for the research were obtained using a questionnaire distributed to 455 respondents. The participants were recruited using purposive sampling method. All of the respondents had stayed in Horison Hotels West Java Area at least 1 time in the last 12 months. The research data were analyzed using LISREL 8.80 to test the models and hypotheses. The results showed that brand image, price and service quality have a positive influence on purchase decisions. Service quality obtained highest score of 0.56 than brand image which obtained a score of 0.22 also Price obtained a score of 0,19 . Future research is expected to focus on other variables such as brand relationship, brand performance, and consumer brand identification. This research provides an understanding of purchase decisions in hotel industry.
\end{abstract}

Keywords: Hotel Industry, Purchase Decision, Brand Image, Price, Service Quality

\section{INTRODUCTION}

West Java Province has the third largest number of hotels in Indonesia with a total of 314 hotel businesses and 18,095 guests per day, based on data from the Central Bureau of Statistics Central Java 2017. This number is the largest after DKI Jakarta (36,871 guests per day ) and Bali (26,632 guests per day). Various hotel management brands appear to show fairly rapid growth. A number of well-known local brands include: Santika, Horison, Sahid, Dafam. International brands that are already operating; Accor, Hyatt, Starwood Hotels, Inter-Continental Hotels Group, Hilton, Archipelago International and Swiss-Belhotel.

The competition faced resulted in high levels of competition faced by the Horizon group Hotel group in West Java, the occupancy rate of the Horison Hotel group was still below the occupancy rate of other hotel goups in West Java.
In terms of prices, and the popularity of the Horison hotel is somewhat less than its competitors in West Java. Most of the verification exhibited that selects purchaser unwillingness does not guarantee that your satisfied customer will be held with you or will benefit your organizations afresh. It is only the buyer, that is basically significant than customer unwaveringness for business accomplishment [1]. The general impression made on the brains of people in general about a lodging can be viewed as a hotel image. Image can in like manner be delineated as feelings, practices or impressions of an individual or a social event regarding a subject. This subject can be a firm, item, brand, objective or person. What is basic is that image shape practices and lead customers to settle on decisions in perspective of them [2].

The purpose of this study are: (1) to determine the effect of brand image on purchase decisions on Horison Hotels group in West Java. (2) to find out the effect of the price on the purchase decision on Horison Hotels group in West Java. (3) to determine the effect of service quality on purchase decisions on Horison Hotels in West Java. (4) to determine the effect of brand image, price and service quality simultaneously on purchase decisions on Horison Hotel customers' group in the West Java Area.

\section{LITERATURE REVIEW}

Brand Image. Brands as names that affect buyers, or names that have the ability to influence buyers. Collective reflection formed by the accumulation of personal experience, closeness of relationships, word of mouth and advertising. Brand image is essentially what comes into the buyers' mind when a brand is presented before the client. An association's image is an essential variable that decides or controversially impacts showcasing exercises. Image is considered to be able to impact clients' views of the products and advertised ventures. Therefore, picture will affect clients' purchasing conduct. Dimensions - The dimensions of the hotel The image that will be used in this study is based on Kandampully \& Suhartanto, namely: Image Attribute as based on guest perception of the hotel location, physical facilities, price, interior design, the quality of goods and services provided and staff performance. Image Holistic based on guest perception 
of hotel atmosphere, reputation, external appearance and layout [3]. Brand image is essentially what comes into the buyers' mind when a brand is presented before the client. When clients evaluate a brand name, they suddenly think about the highlights of a brand [9].

Brand image as a perception and belief held by the consumer reflected by the association of the brand in the consumer's memory. The formation of a positive brand image, which is a strong, profitable, and unique memory or association about the brand goes hand in hand with the formation of brand awareness which is the basis of consumerbased brand equity. Brand image is a reflection of the brand's existence in the minds of consumers. In simple terms the brand image is basically what is obtained in the minds of consumers when the brand is confronted in front of consumers. Hotel Image is an important element of a hotel, brand image acts as the most influential part of service due to its natural uniqueness such as perishable, cannot be shared, tangible and heterogeneous [4]

Corporate image usually describes it as the overall impression made on the minds of the public about a firm. Corporate image is considered as one of the most important intangible assets of the firm. A solid brand must have the capacity to improve corporate value, financial performance, occupancy rate, average room price, level of sales and profits [5]. Brand image is explained as a series of perceptions that result from the relationships that exist between customers and a brand.

Price. Price is all forms of monetary costs sacrificed by consumers to obtain, own, utilize a number of combinations of goods and services from a product, pricing is a way to differentiate offers from competitors. The price is the component of the showcasing blend that produces income; alternate components create costs. They likewise expressed that buy choices depend on how shoppers see costs and what they see the current genuine cost as. Seeing how purchasers touch their impression of costs is an imperative promoting need [6].

As one of advertising blend components, price plays influencing client purchasing choice the most, as the aftereffect of their exploration, travel specialists can hold existing clients by offering and appealing and focused cost, and by giving exceptional rebates [7]. Price is one of promoting blend components which influencing client purchasing choice the most, as the aftereffect of their exploration, travel operators can hold existing clients by offering and appealing and focused cost, and by giving exceptional rebates. Price ought to mirror the esteem buyers will pay versus Price ought to reflect just the expense of making an item or conveying an administrations [8].

Price has two main roles in the decision-making process of buyers, namely the role of allocation and the role of information. Price elements that are often the focus of research are price awareness, price information, and price comparisons between brands, as well as price sensitivity. Price awareness is the ability of consumers to remember the price of both the price of the product itself and the price of the competitor's product to be used as a reference. Price is an important factor in determining the purchase decision of a product or brand [11]. Price can be seen from the combined interaction of these factors, the relative importance of which may vary depending on what is more decisive for the consumer [10].

The dimensions that will be used are: price transparency, price compatibility with quality, price competitiveness and price suitability with benefits. The price of the product or service provided by the company is a means for the company to obtain its financial goals, namely profit. Prices are the same as financial sacrifices that consumers want to buy to buy the product or service they want. Determination of selling prices is basically two types of room prices, namely normal room prices and special room prices. Some examples of special room rates are: walk-in guest rate, group rate, travel agent rate, corporate rate, embassy rate, airline crew rate, weekend rate, membership card rate, government rate, long staying guest rate.

Service Quality. The most popular model for measuring service quality is the SERVQUAL model developed by Parasuraman et al. SERVQUAL model articulated five dimensions of Service Quality (tangible, reliability, assurance and empathy). That performance is an importance factor in measuring Service Quality and argued that their model based on performance [12].

The five dimensions to measure the quality of these services are as follows:

1. Reliability is the ability of a firm to act in accordance their promises reliably and accurately.

2. Responsiveness is the willingness to help consumers and provide services immediately.

3. Assurance is the knowledge and attitude of polite employees, confident and trustworthy.

4. Tangibles are physical things (display of physical facilities, personnel and written material).

5. Empathy is a company that understands its customers' problems and acts in the interests.

The word quality has a different meaning for each person, depending on the context. Administration quality, for example, in the inn business, it is hard to comprehend contrasted and quality items on the grounds that the previous is elusive. A few examinations revealed that the SERVQUAL scale isn't widespread in light of the fact that the quality of administration is obviously relies upon the kind of administration inspected [13].

Regularly, perceived quality has been viewed as one of the most imperative precursors of consumer loyalty and conduct aims in the administration business [14].

Hotels must be able to make changes by considering the internal paradigm and external diagnostics to realize a coherent image. Hotel image and service quality alone are not enough, with the increasingly high level of competition in the current hotel industry, competitive prices are the determining factor for consumers. Hotel pricing is determined by hotel differentiation that takes into account the location, management, staff, guest ratio, and architectural quality, decoration, furniture, fittings, layout or interior design factors.

Purchase decisions. The purchase decisions are based on how consumers consider the current price and what the actual price they are considering is not the price stated by the 
marketer. The criteria that effect travelers' hotel area decision are resolved from the writing, on the web surveys of a given goal's inns, and specialists' conclusions [16]. The dimensions that will be used are: problem recognition, information retrieval, alternative evaluation, purchasing decisions and post-purchase behavior.

The nearness or non attendance of procurement objectives might be related with certain inquiry attributes and perusing designs, which thus affects consumers' purchase decisions. Consequently, to comprehend the job of shoppers' buy objective and its directing effect on the connection between online surveys and customers' buy choice is fundamental to the two academicians and experts [15].

Research hypothesis:

H1 : Brand Image has a positive influence on purchase decisions.

$\mathrm{H} 2$ : Price has a positive influence on purchase decisions.

H3 : Service quality has a positive influence on purchase decisions.

H4 : There is a simultaneous influence on brand image, room price and service quality on purchase decisions.

\section{METHODS}

Research methods with a theoretical lens approach in quantitative research. Testing hypotheses that aim to test hypotheses. The data used is cross sectional data and use survey methods. Data sources are customers of Horison Hotel who are using and who are occupying rooms in the Horison group in the West Java area. Data collection was conducted to obtain primary and secondary data with the following stages: Primary Data: Observation, Distribution of Questionnaires distributed to a number of 455 respondents This number can meet the base necessity of review explore that is 100-200 respondents [18].

Questionnaire contains questions about brand image, price, service quality and purchasing decisions. Each question contains 5 (five) alternative answers with a Likert scale for hotel customers who have used and are using Hotel services. The population in this study were the guests who had been and were staying at the Horison Hotels group in West Java in the Oct-Dec 2016. The sampling was determined by the stratified random sampling method based on the number of consumers in each Horison Hotels in West Java based on company data. The number of samples was set at 455 people based on the guidelines for the number of questionnaire indicator items. Validity Test to show the extent to which a measuring instrument is suitable for measuring. Reliability relates to the degree of consistency or accuracy of data at certain time intervals [16]. Data Normality Test is done to find out whether a data follows a normal distribution or not. The design of quantitative analysis is in the form of hypothesis testing using statistical tests. Data is extracted from hotel industry and data analysis with a quantitative approach, namely with Structural Equation Modeling statistics (SEM).

\section{RESULTS AND DISCUSSIONS}

Characteristics of respondents were the guests who had been and were staying at the Horison group in West Java for the October-Dec 2016. Composition of gender for all respondents consisting of 455 people, male 345 people (76\%) and female 110 people (24\%). The level of education, the majority of them have the last education Bachelor (D4/S1) 155 people (34\%), Diploma 105 people (23\%), high school /vocational school graduates 96 people (21\%), Masters (S2) 50 people (11\%), there are 36 doctoral graduates (S3), and 14 junior high school graduates $(3 \%)$.

The majority of respondents worked as civil servants: 146 people (32\%), BUMN employees: 100 people (22\%), private employees: 59 people (13\%), entrepreneurs: 50 people $(11 \%)$, professionals: 36 people (8\%), TNI / Polri: 23 people $(5 \%)$, freelancers: 18 people (4\%), Housewives: 14 people (3\%), and students: 9 people $(2 \%)$

Hotel Location. The majority of respondents staying at the Horizon hotel are:

- Hosiron Bekasi 84 people (19\%),

- Horison Bandung 80 people $(18 \%)$

- Horision Jababeka Cikarang 61 people (13\%)

- Horison Kuningan 54 people (12\%)

- The Arch by Horison Bogor 48 people (11\%)

- Horison Pangandaran 43 people (9\%)

- Horison Tasikmalaya 43 people (9\%)

- Horison Sukabumi 43 people (9\%).

Effect of Brand Image, Price and Quality of Service on Purchase Decisions. The purpose of this study was to determine the effect of brand image, service quality and price on customer purchase decision at the Horison Hotels in West Java, with a series of quantitative analyzes relevant to the research objectives.

Structural Equation Modeling (SEM) has two types of models formed, namely measurement models and structural models. After the measurement model of each latent variable is described next, a structural model will be described which will examine the effect of each independent latent variable on the dependent latent variable.

Data Normality Test. Based on the output of the SEM analysis, the absolute standard residual value of the covariance matrix is the smallest is close to zero 0.000 [cov $(\mathrm{X} 3, \mathrm{Y} 2)]$ while the largest is 2.56 [cov (KL2, CM2)].

Test Measurement Model. Test of the LISREL program measurement model for each variable is as follows:

Table 1. Summary of Measurement Test Model for the Effect of Brand Image, Price and Service Quality to Purchase Decisions

\begin{tabular}{|c|c|c|c|c|c|c|}
\hline \multicolumn{2}{|c|}{$\begin{array}{l}\text { Measurement } \\
\text { Model }\end{array}$} & \multirow{2}{*}{$\begin{array}{c}\text { Koefio } \\
\text { sien } \\
\text { Value } \\
\text { Factor }\end{array}$} & \multirow{2}{*}{$\begin{array}{c}\text { Stand } \\
\text { ard } \\
\text { Error }\end{array}$} & \multirow{2}{*}{$\begin{array}{c}\text { Val } \\
\text { ue } \\
\text { t- } \\
\text { cou } \\
\text { nt }\end{array}$} & \multirow{2}{*}{ 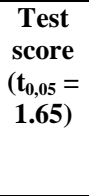 } & \multirow{2}{*}{$\begin{array}{c}\text { Constr } \\
\text { uct } \\
\text { Reliabi } \\
\text { lity } \\
\left(\mathbf{R}^{2}\right)\end{array}$} \\
\hline $\begin{array}{c}\text { Laten } \\
t \\
\text { Varia } \\
\text { ble }\end{array}$ & $\begin{array}{l}\text { Manifest } \\
\text { Variables }\end{array}$ & & & & & \\
\hline \multirow[t]{2}{*}{$\begin{array}{l}\text { Brand } \\
\text { Image }\end{array}$} & $\begin{array}{c}\text { Image } \\
\text { Attribute }\end{array}$ & 0.67 & 0.95 & 1.96 & $\begin{array}{c}\text { Signifi } \\
\text { cant }\end{array}$ & 0.44 \\
\hline & $\begin{array}{c}\text { Image } \\
\text { Holistic }\end{array}$ & 0.74 & 0.073 & $\begin{array}{c}12.8 \\
70\end{array}$ & $\begin{array}{c}\text { Signifi } \\
\text { cant }\end{array}$ & 0.55 \\
\hline Price & $\begin{array}{c}\text { Price } \\
\text { transparen } \\
\text { cy }\end{array}$ & 0.69 & 0.079 & $\begin{array}{c}12.5 \\
40\end{array}$ & $\begin{array}{c}\text { Signifi } \\
\text { cant }\end{array}$ & 0.48 \\
\hline
\end{tabular}




\begin{tabular}{|c|c|c|c|c|c|c|}
\hline \multicolumn{2}{|c|}{$\begin{array}{c}\text { Measurement } \\
\text { Model }\end{array}$} & \multirow{2}{*}{$\begin{array}{c}\text { Koefio } \\
\text { sien } \\
\text { Value } \\
\text { Factor }\end{array}$} & \multirow{2}{*}{$\begin{array}{l}\text { Stand } \\
\text { ard } \\
\text { Error }\end{array}$} & \multirow{2}{*}{$\begin{array}{c}\text { Val } \\
\text { ue } \\
\text { t- } \\
\text { cou } \\
\text { nt }\end{array}$} & \multirow{2}{*}{ 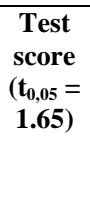 } & \multirow{2}{*}{$\begin{array}{c}\text { Constr } \\
\text { uct } \\
\text { Reliabi } \\
\text { lity } \\
\left(\mathbf{R}^{2}\right)\end{array}$} \\
\hline $\begin{array}{c}\text { Laten } \\
t \\
\text { Varia }\end{array}$ & $\begin{array}{c}\text { Manifest } \\
\text { Variables }\end{array}$ & & & & & \\
\hline & $\begin{array}{c}\text { Price } \\
\text { compatibil } \\
\text { ity with } \\
\text { quality }\end{array}$ & 0.83 & 0.11 & $\begin{array}{c}14.7 \\
90\end{array}$ & $\begin{array}{c}\text { Signifi } \\
\text { cant }\end{array}$ & 0.68 \\
\hline & $\begin{array}{c}\text { Price } \\
\text { competitiv } \\
\text { eness }\end{array}$ & 0.63 & 0.10 & $\begin{array}{c}11.8 \\
8\end{array}$ & $\begin{array}{c}\text { Signifi } \\
\text { cant }\end{array}$ & 0.39 \\
\hline & $\begin{array}{c}\text { Price } \\
\text { suitability } \\
\text { with } \\
\text { benefits }\end{array}$ & 0.13 & 0.060 & 2.60 & & 0.018 \\
\hline \multirow{5}{*}{$\begin{array}{l}\text { Sevice } \\
\text { Qualit } \\
\text { y }\end{array}$} & Tangibles & 0.72 & 0.16 & 9.82 & $\begin{array}{c}\text { Signifi } \\
\text { cant }\end{array}$ & 0.52 \\
\hline & Reliability & 0.73 & 0.095 & $\begin{array}{c}11.5 \\
9 \\
\end{array}$ & $\begin{array}{c}\text { Signifi } \\
\text { cant }\end{array}$ & 0.53 \\
\hline & $\begin{array}{c}\text { Responsiv } \\
\text { eness }\end{array}$ & 0.87 & 0.087 & 9.99 & $\begin{array}{c}\text { Signifi } \\
\text { cant }\end{array}$ & 0.33 \\
\hline & Assurance & 0.33 & 0.091 & 6.03 & $\begin{array}{c}\text { Signifi } \\
\text { cant }\end{array}$ & 0.11 \\
\hline & Emphaty & 0.34 & 0.093 & 6.15 & $\begin{array}{c}\text { Signifi } \\
\text { cant }\end{array}$ & 0.11 \\
\hline \multirow{5}{*}{$\begin{array}{l}\text { Purch } \\
\text { ase } \\
\text { Decisi } \\
\text { ons }\end{array}$} & $\begin{array}{c}\text { Problem } \\
\text { recognitio } \\
n\end{array}$ & 0.85 & 0.17 & $\begin{array}{c}13.5 \\
7\end{array}$ & $\begin{array}{c}\text { Signifi } \\
\text { cant }\end{array}$ & 0.18 \\
\hline & $\begin{array}{l}\text { Informatio } \\
\text { n retrieval }\end{array}$ & 0.61 & 0.12 & $\begin{array}{c}17.4 \\
5 \\
\end{array}$ & $\begin{array}{c}\text { Signifi } \\
\text { cant }\end{array}$ & 0.21 \\
\hline & $\begin{array}{c}\text { Alternatif } \\
\text { Evaluation }\end{array}$ & 0.77 & 0.22 & $\begin{array}{c}19.5 \\
5\end{array}$ & $\begin{array}{c}\text { Signifi } \\
\text { cant }\end{array}$ & 0.20 \\
\hline & $\begin{array}{l}\text { Purchassin } \\
\text { g decision }\end{array}$ & 0.82 & 0.23 & $\begin{array}{c}20.6 \\
5\end{array}$ & $\begin{array}{c}\text { Signifi } \\
\text { cant }\end{array}$ & 0.16 \\
\hline & $\begin{array}{c}\text { Post- } \\
\text { purchase } \\
\text { behavior }\end{array}$ & 0.58 & 0.091 & 7.49 & $\begin{array}{c}\text { Signifi } \\
\text { cant }\end{array}$ & 0.34 \\
\hline
\end{tabular}

Source : Data Analysis, 2017

Based on Table 1 it can be concluded that the weighting factor coefficient (Standardized) Measurement Model in this study has a significant effect, meaning that all manifest variables can explain each of the latent variables well. The results of the path coefficient analysis confirmatory factor analysis (CFA) model shows a significant influence, as shown in the table above the calculated value (C.R / critical ratio) all above the critical value required, namely C.R $\square 1.645$. So it can be concluded that all dimensions can explain each variable. Structural Model 1, describes the relationship between brand image, price and service quality with purchasing decisions, which are stated in the hypothesis as follows: that brand image, price and service quality significantly influence purchasing decisions both simultaneously and partially. Based on the results of the LISREL program data processing for structural model 1 , in accordance with the proposed hypothesis are as follows:

$\mathrm{PD}=0.22 * \mathrm{BI}+0.19 *$ Price $+0.56 * \mathrm{SQ}$

$$
\begin{array}{lll}
(0.27) & (0.87) & (0.061) \\
1.77 & 1.74 & 1.76
\end{array}
$$

Errorvar. $=0.23, \mathrm{R} 2=0.77$

Based on the above equation can be explained as follows. There is a degree of contribution from the brand image variable to the purchase decision of 0.22 , so that the better the Horison Hotel group brand image, it will contribute to the purchasing decision of 0.22 . There is a degree of contribution from the price variable to the purchase decision of 0.19 , so the better the price of the Horison Group Hotel, it will contribute to the purchase decision of 0.19 .

There is a degree of contribution from the service quality variable to the purchase decision of 0.56 , so that the better the service quality of the Hotel Horison Group, it will contribute to the purchase decisions of 0.56 . The data processing results also show the R2 value for the above equation is 0.77 . This illustrates that purchasing decisions are influenced simultaneously by brand image, price and service quality. This value also indicates that there are other factors that influence purchasing decisions outside the brand image factor, price and service quality which are addressed by variant errors that are equal to 0.23 . Thus, the proposed conceptual hypothesis has been tested and accepted. The complete structural model for substructure 1 can be seen in Figure 1.

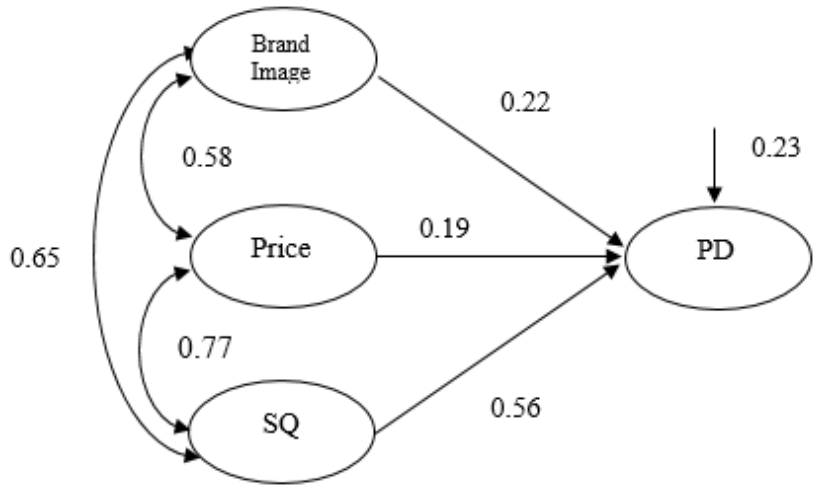

Figure 1. Pathway coefficient of brand image, price and service quality to purchase decision

The calculation results obtained show that the purchase decision is influenced by the brand image, price and service quality both partially and simultaneously. Based on correlation values and path coefficients obtained from the results of calculations with Lisrel can be known the magnitude of the direct and indirect influence of brand image, price and service quality on purchasing decisions as follows:

\begin{tabular}{|c|c|c|c|c|c|c|}
\hline \multirow{2}{*}{ Variable } & \multirow{2}{*}{$\begin{array}{c}\text { Direct } \\
\text { impact } \\
\text { to } Y_{1} \\
\end{array}$} & \multicolumn{3}{|c|}{ Undirect impact } & \multirow{2}{*}{$\begin{array}{c}\text { Total } \\
\text { direct } \\
\text { impact }\end{array}$} & \multirow{2}{*}{$\begin{array}{c}\text { Total } \\
\text { impact }\end{array}$} \\
\hline & & $\mathbf{X}_{1}$ & $\mathbf{X}_{2}$ & $\mathbf{X}_{3}$ & & \\
\hline $\mathrm{X}_{1}$ & 0,05 & & 0,02 & 0,08 & 0,11 & 0,15 \\
\hline $\mathrm{X}_{2}$ & 0,04 & 0,02 & & 0,08 & 0,11 & 0,14 \\
\hline $\mathrm{X}_{3}$ & 0,31 & 0,08 & 0,08 & & 0,16 & 0,48 \\
\hline \multicolumn{6}{|c|}{ l effect } & $\mathbf{0 , 7 7}$ \\
\hline
\end{tabular}

Table 2. Direct and indirect influence of brand image, price and service quality on purchase decisions

Source : Data Processing 2017

Based on the table 2 above, it can be seen that the influence of brand image, price and service quality on purchasing decisions is influenced by direct and indirect influences.

The direct effect of brand image variables on purchasing decisions is $5 \%$ while the indirect effect is $11 \%$, namely through price and service quality variables. The indirect effect of brand image on purchasing decisions is greater than the direct influence, this indicates that the brand image applied by the company has not been maximized so there needs to be a contribution of price and service quality. Thus the influence 
of brand image on purchasing decisions both directly and indirectly is $15 \%$.

The direct effect of the price variable on purchasing decisions is $4 \%$ while the indirect effect is $11 \%$, namely through the brand image and service quality variables. The indirect effect of the price on purchasing decisions is greater than the direct effect, this indicates that the price applied by the company is not good so there is a need for contributions from brand image and service quality. Thus the influence of prices on purchasing decisions both directly and indirectly is $14 \%$.

The direct effect of service quality variables on purchasing decisions is $31 \%$ while the indirect effect is $16 \%$, namely through brand image and price variables. The direct influence of service quality on purchasing decisions is greater than the indirect effect, this indicates that the quality of service implemented by the company has been relatively good despite the contribution of brand image and prices. Thus the influence of service quality on purchasing decisions both directly and indirectly is $48 \%$.

In addition to the three variables above, there are still many other variables that influence the purchase decision because it is based on the influence outside the model that is equal to 0.23 , meaning that the purchase decision is influenced by variables outside the research model by $23 \%$.

Furthermore, hypothesis testing is conducted to prove the significance of the influence of brand image, price and service quality on purchase decisions.

First Hipotesis

$\mathrm{H}_{0}: \gamma_{3.1}=0$

Brand image does not affect purchasing decisions

$\mathrm{H}_{1:} \gamma_{3.1} \neq 0 \quad$ Brand image affects purchasing decisions

The results of testing the influence of brand image on purchasing decisions as contained in the table 3 below.

Table 3. Effect of Brand Image on Purchase Decisions

\begin{tabular}{|c|c|c|c|c|}
\hline $\begin{array}{c}\text { Path } \\
\text { Coefficient }\end{array}$ & $\mathbf{t}_{\text {count }}$ & $\mathbf{t}_{\text {table }}$ & $\mathbf{H}_{\mathbf{0}}$ & $\mathbf{H}_{\mathbf{1}}$ \\
\hline 0.22 & 1.77 & 1.64 & Rejected & Accepted \\
\hline
\end{tabular}

Source : Data Processing 2017

Based on the test results above, it can be seen that the value of tcount of brand image variable (1.77) is greater than t table (1.64). Because the tcount is greater than t table, then with a $5 \%$ error rate it is decided to reject $\mathrm{H} 0$ so that $\mathrm{H} 1$ is accepted. So based on the test it can be concluded that the brand image has a significant influence on purchasing decisions in the Horison Hotel Group in West Java. The results of this test provide empirical evidence that the better the brand image will increase purchasing decisions.

Second Hypothesis
$\mathrm{H}_{0}: \gamma_{3.2}=0$
Price does not affect the purchase decisions
$\mathrm{H}_{1}: \gamma_{3.2} \neq 0$
Prices affect the purchase decisions

The results of testing the effect of prices on purchasing decisions as contained in the table 4 below.
Table 4. Effect of Price on Purchase Decisions

\begin{tabular}{|c|c|c|c|c|}
\hline $\begin{array}{c}\text { Path } \\
\text { Coefficient }\end{array}$ & $\mathbf{t}_{\text {count }}$ & $\mathbf{t}_{\text {table }}$ & $\mathbf{H}_{\mathbf{0}}$ & $\mathbf{H}_{\mathbf{1}}$ \\
\hline 0.19 & 1.74 & 1.64 & Rejected & Accepted \\
\hline
\end{tabular}

Based on the test results above, it can be seen that the tcount of the price variable (1.74) is greater than t table (1.64). Because the tcount is greater than $t$ table, then with a $5 \%$ error rate it is decided to reject $\mathrm{H} 0$ so that $\mathrm{H} 1$ is accepted. So based on the test it can be concluded that the price has a significant effect on purchasing decisions in the Horison Hotel Group in West Java. The results of this test provide empirical evidence that the better the price will increase purchasing decisions.

Third Hypothesis

$\mathrm{H}_{0}: \gamma_{3.3}=0 \quad$ Service quality does not affect the purchase decisions

$\mathrm{H}_{1}: \gamma_{3.3} \neq 0 \quad$ Service quality affect the purchase decisions

The results of testing the effect of prices on purchasing decisions as contained in the table 5 below.

Table 5. Effect of Service Quality on Purchase Decisions

\begin{tabular}{|c|c|c|c|c|}
\hline $\begin{array}{c}\text { Path } \\
\text { Coefficient }\end{array}$ & $\mathbf{t}_{\text {count }}$ & $\mathbf{t}_{\text {table }}$ & $\mathbf{H}_{\mathbf{0}}$ & $\mathbf{H}_{\mathbf{1}}$ \\
\hline 0.56 & 1.76 & 1.64 & Rejected & Accepted \\
\hline
\end{tabular}

Based on the test results above, it can be seen that the tcount of service quality variables (1.76) is greater than $t$ table (1.64). Because the tcount is greater than t table, then with a $5 \%$ error rate it is decided to reject $\mathrm{H} 0$ so that $\mathrm{H} 1$ is accepted. So based on testing, it can be concluded that service quality has a significant effect on purchasing decisions in the Horison Hotel Group in West Java. The results of this test provide empirical evidence that the better the quality of service will improve purchasing decisions.

Fourth Hypothesis

$\mathrm{H}_{0}:$ All $\beta_{3 . \mathrm{i}} \& \gamma_{3 . \mathrm{i}}=0 \quad$ Brand image, price and service quality have no simultaneous effect on purchasing decisions

$\mathrm{H}_{1}$ : Any $\beta_{3 . \mathrm{i}} \& \gamma 3 . \mathrm{i} \neq 0$ Brand image, price and service quality have simultaneous effect on purchasing decisions

$\mathrm{i}=1,2,3$

With the test criteria: Reject $\mathrm{H}_{0}$ if $\mathrm{F}_{\text {count }}>\mathrm{F}_{\text {table }}$

From table $\mathrm{F}$ for the 0.05 level of significance and degree of freedom $(3 ; 451)$, the Ftable value is 2,625 . Because the results of the study obtained Fcount value $(11.32)$ is greater than Ftable $(2,625)$, then the error rate of $5 \%$ was decided to reject $\mathrm{H} 0$ so that $\mathrm{H} 1$ was accepted. So based on the test, it can be concluded that the brand image, price and service quality together have a significant effect on purchasing decisions in the Horison Hotel Group in West Java.

Based on the research results can be concluded as follows. The results of testing the first hypothesis shows that the brand image has a positive effect on purchasing decisions. By showing the results that the highest-dimensional brand image is a holistic image with a value of 0.74 and the lowest image 
attribute with a value of 0.67 . Where the highest purchasing decision dimension is problem recognition with a value of 0.85 and the lowest value of post purchase behavior with a value of 0.58 . The results of the study support and in accordance with the research of Kandampully \& Suhartanto, (2000) revealed that brand image is a perception of accumulation of various experiences in the hotel where the consumer lives, the relationship between service characteristics is tangible and intangibily.

The result of testing the second hypothesis shows the result that the price has a positive effect on the purchase decisions. By showing the result that the price with the highest dimension is the price suitability with the quality of the product with a value of 0.83 and the lowest price match with the benefit with a value of 0.13 . Where the highest purchasing decision dimension is problem recognition with a value of 0.85 and the lowest value of post purchase behavior with a value of 0.58 . Pricing strategies are very significant in providing value to consumers and influencing product image, and consumer decisions to buy. Pricing is also related to income and also influences the demand for marketing channels. Decisions in pricing must be consistent with the overall marketing strategy.

The results of the third hypothesis testing show that service quality has a positive effect on purchasing decisions. By showing the results that the service quality with the highest dimensions is responsiveness with a value of 0.87 and the lowest assurance with a value of 0.33 . Where the highest purchasing decisions dimension is problem recognition with a value of 0.85 and the lowest value of post purchase behavior with a value of 0.58 . Service quality has a significant effect on purchasing decisions. The dimensions of service quality that give the most dominant influence are tangible dimensions with indicators of neat and clean-looking employees as the most dominant indicator that has an effect on tangible. This was supported by the respondents' assessment where respondents rated the services provided to be of good quality so they decided to stay.

The results of testing the fourth hypothesis shows that there is an influence of brand image, price, and service quality together on Purchase Decisions. In this study the multiple determination coefficient is used to determine the magnitude of the variation of independent variables that can explain the variation of the dependent variable. Based on the Model Summary table, the coefficient of determination (R2) is 0.77 or $77 \%$. This means that the Brand Image, Price and Quality of Service together for the Purchase Dcision together or simultaneously by $77 \%$ and the remaining $23 \%$ are other factors not included in the research model

\section{CONCLUSIONS}

Related to the brand image, things that need to be improved include improvements to the Wifi internet network by setting up technology infrastructure in the form of internet networks and setting the standard mbps that must be available on each existing property. (standard implementation of 50-100 mbps per property). The provision of infrastructure will provide additional services for customers who can meet customer expectations for the needs of technology services and ultimately will provide a positive image for Management. There is an assessment that is still below the average on the indicator "Horison Hotel has a reputation as the best choice for hotels in West Java and the arrangement of the layout of the rooms (lobby, reception, restroom) is good and right". This is an input for Management to be able to pay attention to aspects of the holistic image. Arrangement of appropriate space layout, comfortable room and good level of lighting will influence consumer valuation after using existing room facilities.

Relating to prices, things that must be improved through improving the quality of hotel rooms and services by hotel employees, periodically evaluating room rates so that they can compete and suit room rates with services received by guests, as well as a discount program for certain moments for example guests who are having a birthday. Horison Hotel offers attractive discounts. By applying the effective BAR method, the Best Available Rate Method: by applying sales forecasting and seeing the market trend.

Relating to the quality of service, there is supervision by the supervisor so that the services provided are as promised, information when guests check in and check out as stated, clarity of information about the facilities that guests get during the stay, employee training in order to improve knowledge and skills are carried out regularly.

Tangible dimensions, where the lighting aspect of the lobby area and room. An aspect that gets less judgment. For this reason, the Management must have a standard of how many lights and lumens are the basis for determining each area (lobby, bedroom, living room, bathroom, corridor and public area as well as the use of LED lights.

Reliability Dimension which provides services as promised in the existing slogan. Controlling from the supervisor on an ongoing basis can be monitored by guest comments. Each shift can be evaluated by the Manager if there is input to be followed up and decision making from the Manager. Staff response in providing information about facilities during the stay. After knowing the level of understanding, a training program is prepared as needed.

Dimensions of Assurance where the Horizon Hotel Staff is always honest and trustworthy. It can be done by carrying out a guest mystery to find out directly how the level of service provided by the employee by example: the guest leaves the item in the room, with that it can find out the handling of items that are left behind by the guest (lost and found procedures).

Emphaty dimension where by giving personal attention to customers in their services and Horizon Hotel staff can be contacted at any time during my stay. Can quickly provide services if there are guests who look confused in the hotel area by directly arriving and offering assistance

Some of the problems related to the customer purchase decisions of the Horison Hotel group in West Java are improvements namely building customer relationship management through personal service, always looking for information about the needs of guests who are always changing and different in each segment.

Further research considers that it can be done in other operator hotels or in 5 and 3 star hotels and can conduct research in other areas other than West Java. Subsequent research can develop other variables which consist of 3 dimensions, namely relationship brand, hotel brand performance and brand identification consumer, therefore 
further research can consider testing the relationship quality dimension to other variables.

\section{ACKNOWLEDGMENT}

The authors are grateful to Binus University especially to Prof. Tirta Nugraha Mursitama, S.Sos., MM., Ph.D as Vice Rector Research \& Technology Transfer and Pak Trias S.Putranto.,SST.Par., MM., CHE. as Head of Hotel Management Department who provides the facilities required also fully support for the finalization of all the research.

\section{REFERENCES}

[1] H. Saleem and N. S. Raja, "The Impact of Service Quality on Customer Satisfaction, Customer Loyalty and Brand Image: Evidence from Hotel Industry of Pakistan," Middle-East Journal of Scientific Research 19 (5), pp. 706-711, 2014

[2] U. Durna and B. B. Dedeoglu, "The role of servicescape and image perceptions of customers on behavioral intentions in the hotel industry.," International Journal of Contemporary Hospitality Management, vol. Vol.27 No.7, pp. 1728-1748., 2015.

[3] J. Kandampully and D. Suhartanto, "'Customer loyalty in the hotel industry: the Role Of Customer Satisfaction and image"," International Journal of Contemporary Hospitality Management., vol. 12/6, pp. Kandampully, Jay \& Suhartanto, Dwi. 2000. "Customer loyalty in the hotel industry: the Role Of Customer Satisfaction and image", Interna346-351, 2000.

[4] D. D. Mirandaa and R. C. Garcia, "Image Management of The Hotel: A Complementary Approach Between Intangible And Tangible Resources," International Academic Journal of Business Management, Vols. Vol. 4, No. 1, pp. pp. 50-62, 2017.

[5] B. Milfelner and A. P. Korda, "Hotel image and guests satisfaction as a source of sustainable competitive advantage," Int. J. Sustainable Economy, Vol. 3, No. 1, 2011, Vols. Vol. 3, No. 1, pp. pp. 92-106, 2011.

[6] H. Al-Salamin and E. Al-Hassan, "The Impact of Pricing on Consumer Buying Behavior in Saudi Arabia : AlHassa Case Study," European Journal of Business and Management, Vols. Vol.8, No.12, 2016, pp. pp. 62-74, Vol.8, No.12, 2016.

[7] N. H. Zhafira, J. . Andreti, S. S. Akmal and S. Kumar "The Analysis of Product, Price, Place, Promotion and Service Quality on Customers' Buying Decision of Convenience Store: A Survey of Young Adult in Bekasi, West Java, Indonesia," International Journal of Advances in Management and Economics, Vols. Vol.2 | Issue 6|7278, pp. pp. 72-78, Nov, - Dec. 2013.

[8] M. Hunold, R. Kesler, U. Laitenberger and F. Schultter, "Evaluation of Best Price Clauses in Online Hotel Bookings," International Journal of Industrial Organization, vol. INDOR 2439, pp. pp. 1-34, 2018.

[9] J. Lahap, "A Study of Brand Image towards Customer's Satisfaction in the Malaysian Hotel Industry," Lahap, Johanudin et al. 2016. "A Study of Brand Image towards Customer's Satisfaction in the Malaysian Hotel Industry", Procedia - Social and Behavioral Sciences 224 (2016) 149 - 157. ScienceDirect. 1877-0428 (C) 2016, Elsevier Ltd, vol. 224, pp. 149-157, 2016.

[10] G. Abrate and G. Viglia, "Strategic and tactical price decisions in hotel revenue management," Tourism Management, vol. 55, pp. 123-132, 2016.

[11] G. K. Nair, "Dynamics of pricing and non-pricing strategies, revenue management performance and competitive advantage in hotel industry," International Journal of Hospitality Management, pp. 1-11, 2018.

[12] Y. Ju, K.-J. Back, Y. Choi and J.-S. Lee, "Exploring Airbnb service quality attributes and their asymmetric effects on customer satisfaction," International Journal of Hospitality Management, pp. 1-11, 2018.

[13] A. N. AbuKhalifeh and A. P. M. Som, "Service Quality Management in Hotel Industry: A Conceptual Framework for Food and Beverage Departments," International Journal of Business and Manegement; Vol. 7, No. 14; 2012, Vols. Vol. 7, No. 14, pp. pp. 135-142, 2012.

[14] Y. Liu and S. (. Jang, "Perceptions of Chinese restaurants in the U.S.: What affects customer satisfaction and behavioral intentions?," International Journal of Hospitality Management, vol. Vol.28, p. pp.338-348, 2009.

[15] F. L. Weisstein, L. Song, P. Andersen and Y. Zhu, "Examining impacts of negative reviews and purchase goals on consumer purchase decision," Journal of Retailing and Consumer Services, vol. Vol.39, pp. pp.201-207, 2017.

[16] S. Aksoy and M. Y. Ozbuk, "Multiple criteria decision making in hotel location: Does it relate to postpurchase consumer evaluations," Tourism Management Perspectives, vol. 22, pp. 73-81, 2017.

[17] W. G. Zikmund, B. J. Babin, J. C. Carr and M. Griffin, Business Research Methods 8th Edition, South-Western, Canada, 2010.

[18] Sugiyono, Metode Penelitian Penekatan Kuantitatif, Kualitatis dan R \& D, Bandung: Alfabeth, 2014. 